\title{
Distribution of sex and age groups of ringed seals Pusa hispida in the fast-ice breeding habitat of Kongsfjorden, Svalbard
}

\author{
Bjørn A. Krafft, Kit M. Kovacs*, Christian Lydersen
}

Norwegian Polar Institute, 9296 Tromsø, Norway

\begin{abstract}
Spatial distribution of various age- and sex groups of ringed seals ( $\mathrm{N}=94 ; 19$ adult males, 33 adult females and 42 subadults) was studied in their fast-ice breeding habitat in Kongsfjorden, Svalbard, during May 2004. Adult females occupied the inner, most stable ice area, while subadults were found predominantly in the outer parts of the fast-ice, where the ice conditions are more unstable. Adult males were scattered across these 2 areas; some were intermingled with breeding females while others were found further out towards the ice edge in areas mainly dominated by subadults. This pattern suggests territorial behaviour with competitive exclusion of the subadults and adult males that cannot compete for territories in the prime breeding areas. The size of adult males was correlated with their testosterone levels, but it was not necessarily the largest males that had the most adult female neighbors. The adult males that had the most adult female neighbors were however significantly older than the adult males with fewer female neighbors ( $18 \pm 1$ vs. $12 \pm 1$ yr). This suggests that experience (age) likely plays a strong role in achieving reproductive success for male ringed seals. A male:female sex ratio of 1:2.4 was found in the prime breeding area, which suggests a slightly polygynous mating system.
\end{abstract}

KEY WORDS: Ringed seal $\cdot$ Pusa hispida $\cdot$ Ice-breeding seals $\cdot$ Mating systems $\cdot$ Sexual segregation Resale or republication not permitted without written consent of the publisher

\section{INTRODUCTION}

Most mammalian mating systems represent various forms of mate guarding adapted to the spatial and temporal distribution of breeding females (Clutton-Brock 1989). Female distribution is, in turn, dependent on factors such as resource distribution and predation pressure. Pinnipeds exhibit a wide range of mating strategies but most are polygynous to some degree (see for reviews Stirling 1975, 1983, Boness 1991, LeBoeuf 1991). The degree of polygyny achieved by males is mainly determined by how tightly breeding females are aggregated in space and time. The most extreme cases of polygyny are found in terrestrial breeding pinnipeds where space is a limited resource. In otariid seals, sexual size dimorphism is taken to an extreme, and harems of over 100 females are encountered in some species (Gentry 1998). For pinnipeds that breed on ice, space is not as limited as for the terrestrial breeders, and most ice-breeding species mate in the water where males are not able to restrict a female's mobility (Boness et al. 1993). Since the females are more spatially dispersed and free to move at will in the water, males have fewer possibilities to defend and mate with large numbers of females. As a consequence, aquatic mating pinnipeds are generally less polygynous and exhibit less size dimorphism compared to those that mate on land (Stirling 1983, but also see Kovacs 1990, Tinker et al. 1995).

Ringed seals Pusa hispida are monomorphic (Lydersen \& Gjertz 1987), ice-breeding phocids that mate in the water (Stirling 1975, 1983). The preferred breeding habitat of ringed seals is stable land-fast ice, where ringed seal densities are usually higher inshore than offshore (Smith \& Stirling 1975, Lydersen \& Gjertz 1986). However, some ringed seals do breed in free-floating packice in several locations (Fedoseev \& Yablokov 1964, Fedoseev 1975, Finley et al. 1983, Wiig et al. 1999). Ringed seals build subnivean lairs excavated on top of 
breathing holes in the ice where they spend time resting during the inclement winter months (e.g. Smith \& Stirling 1975, 1978). Females give birth in a lair, which is often part of a complex of several similar structures in an area, separated by up to $200 \mathrm{~m}$ (Smith \& Hammill 1981). Males also use several lairs, spread through an area that contains the lairs of several females (Kelly \& Quakenbush 1990). Lairs provide protection from harsh environmental conditions and also provide a degree of protection against predation (Smith \& Stirling 1975, Smith 1976, 1980, Lydersen \& Gjertz 1986, Lydersen \& Smith 1989, Smith et al. 1991, Furgal et al. 1996). A female will move a young pup between lairs within her complex if it is attacked by polar bears Ursus maritimus or arctic foxes Alopex lagopus. Older pups are able to shift between structures independently (Lydersen \& Hammill 1993a). The small ringed seal neonates that weigh 4 to $5 \mathrm{~kg}$ (Lydersen et al. 1992) are born with a white lanugo coat that insulates well enough to keep the pups thermoneutral without the shelter of the lair if the fur stays dry (Smith et al. 1991). However, wet pups require the shelter of lairs in order to regain thermoneutrality (Smith et al. 1991). Thus, both the physical and thermal protection provided by these lairs is particularly important for the survival of ringed seal neonates.

Ringed seals have the longest nursing period of the ice-breeding northern phocids with an average duration of $39 \mathrm{~d}$ (Hammill et al. 1991). The pups are able to swim and dive shortly after birth and they develop foraging skills prior to weaning (Lydersen \& Hammill 1993a). Weaning is less abrupt than for most phocid pups where the mothers simply abandon their pups before they have entered the water for the first time (Bowen 1991, Lydersen \& Kovacs 1999).

Many of the larger phocid species are so-called 'capital breeders', which means that they cover the energetic costs of lactation entirely from stored energy reserves (see Costa \& Williams 1999). This is however not the case for all phocids, ringed seals rely heavily on energy obtained from foraging to cover the cost of lactation (Lydersen \& Hammill 1993b, Lydersen 1995, Lydersen \& Kovacs 1999).

Ringed seal females should thus maximize their fitness by ensuring pup survival via choosing stable ice platforms for breeding. The ideal sea-ice platform must be formed well before breeding to ensure enough snow accumulation for lair construction (Smith \& Lydersen 1991, Furgal et al. 1996). The sea ice must in addition be stable throughout the entire lactation period so that mother-pup pairs do not get prematurely separated. In addition, the ice habitat must be large enough to contain sufficient amounts of prey to support the resident animals during the relatively long lactation period. In coastal areas with fjords and bays the preferred breeding habitats tend to be inshore areas, which are most stable, and the size of the areas females occupy are probably determined to some degree by the availability of structures in the ice around which snow accumulate for lair construction, and by the density of available prey organisms in the area (Smith \& Lydersen 1991, Smith et al. 1991).

Adult male ringed seals maximize their fitness by mating with as many females as possible (e.g. Stirling 1975 , 1983). Little is known about the behavior of adult males during this time of the year, but there are reports of aggressive behaviour and fresh bite marks during the breeding season as well as heavy scarring on the hind-flippers of old males (e.g. Smith \& Hammill 1981, Krafft et al. 2006a) that are taken as evidence of territorial fighting. In addition, during the breeding period adult ringed seal males secrete a very strong-smelling oily substance produced by facial sebaceous glands (Ryg et al. 1992). The function of this secretion is likely related to marking of territories (Smith 1987), and the most logical places to mark would be the breathing holes or lairs, since the seals are unlikely to be able to smell under water. Since the breeding females are quite dispersed it has been suggested that males defend territories that overlap with several females, or that they defend individual females serially or simply rove in search of receptive females (Smith \& Hammill 1981, Kelly \& Quakenbush 1990, Boness et al. 2002). Based on direct observations of haul-out behaviour of a few recognizable individual ringed seals, Smith \& Hammill (1981) suggested that breeding units were made up of several adult females that occupied an area defended by a territorial male. This study also suggested that the adult females excluded the resident male from the vicinity of their birth-lair complexes until close to the time pups were weaned.

When the various pieces of evidence about ringed seal breeding behaviour are compiled, it seems reasonable to expect that the various sex and age groups would be spatially segregated during the breeding period, with adult animals occupying the most stable ice areas, while younger animals would be excluded to more unstable ice areas (e.g. McLaren 1958, Smith 1987). The purpose of this study was to examine spatial arrangements of ringed seals in detail to shed light on the mating system of this species. The study was conducted in a fjord where the stability of the sea ice varies substantially from the inner to the outer parts, and our working hypothesis was that the adult females should be found in the innermost areas, while subadult animals should be in the outer unstable ice areas. Adult males should be broadly spread with successful territory holders being distributed close to the adult females, while the adult males that are unable to hold prime territories would be located toward the outside edges of the breeding habitat. 


\section{MATERIALS AND METHODS}

This study was conducted in Kongsfjorden $\left(78^{\circ} 55^{\prime} \mathrm{N}\right.$, $12^{\circ} 30^{\prime}$ E, Fig. 1), Svalbard, from 5 to 21 May 2004. Kongsfjorden is a westward pointing fjord where the outer areas are exposed to wind and waves coming in from the Greenland Sea. The inner parts of Kongsfjorden contain a north to south string of small islands and skerries that protect the innermost basin of the fjord from wind and wave action (Fig. 1). As a consequence, the ice conditions in the outer parts of Kongsfjorden are much more variable and unstable compared to the innermost parts east of the protecting islands that experience much more stable ice conditions and a longer season of ice coverage. Kongsfjorden is known to be a good breeding area for ringed seals, with one of the highest lair densities in Svalbard (Lydersen \& Gjertz 1986, 1987). For this study, Kongsfjorden was divided into an unstable-ice area (Area A, Fig. 1) and a stable-ice area (Area B, Fig. 1). The dividing line between these 2 areas (Fig. 1) follows the string of islands and shallow water from north to south until the last small skerry, which is located at the point in the map where this line breaks off to the east. The whole area of Kongsfjorden south of this point lacks islands and skerries and is thus exposed to wind and wave action from the west. In addition, the glacier located in the southeastern part of the fjord is actively calving and is thus constantly creating wave action that interferes with the formation of fast-ice. In some years this southern part of Kongsfjorden does not have fast-ice at all. During the study period the fast-ice situation in Kongsfjorden was as depicted in Fig. 1, with Area A consisting of about $50 \mathrm{~km}^{2}$ of sea ice and Area B about $38 \mathrm{~km}^{2}$ of fast-ice.

As part of a larger collection program for population studies of ringed seals in Svalbard (see Krafft et al. 2006b for details), 94 animals were shot while hauled out on the fast-ice in Kongsfjorden. Permits to conduct this collection were provided by the Governor of Svalbard (Sysselmannen), and the programme in its entirety was reviewed via the granting process of the National Research Council of Norway. Data on collection point (GPS position), sex, body mass (Salter scale: $100 \pm 0.5 \mathrm{~kg}$ ) and standard length $( \pm 1 \mathrm{~cm})$ were collected from each seal. Blubber thickness was measured mid-dorsally at a point approximately $60 \%$ of the length of the animal from the cranial end, following Ryg et al. (1990a). The lower jaw with teeth was collected; age was determined in the laboratory by counting cementum layers in decalcified, stained longitudinal sections of the canine teeth, following Lydersen \& Gjertz (1987). Teeth were read serially, by multiple readers and any significant differences in age were explored further until consensus was reached. The genitals were frozen $\left(-20^{\circ} \mathrm{C}\right)$ for later analysis (see below). Blood samples of about $50 \mathrm{ml}$ were collected from the extradural intravertebral vein. Plasma was separated by centrifugation within $4 \mathrm{~h}$, at $3000 \mathrm{rpm}$ for $10 \mathrm{~min}$, and stored frozen $\left(-20^{\circ} \mathrm{C}\right.$ ) until analyses (hormonal; other tissues were also collected for additional studies, e.g. Krafft et al. 2006b, Tryland et al. 2006, Labansen et al. 2007). Hunting effort was spread evenly across the study area. Initially, from 5 to 19 May, hunting was focused on subadults and adult males; the latter recognizable via their size, the penile opening and the dark facial region. Adult females were targeted after 20 May, when the general hunting season opened on Svalbard, in order to avoid potential separation of mother-pup pairs. Kongsfjorden was thought to contain a minimum of $\sim 500$ seals (Krafft et al. 2006c) at this time of year, so a maximum a priori take was set at 100 animals.

In the laboratory both ovaries from each female $(\mathrm{N}=45)$ were analyzed

Fig. 1. Study area in Kongsfjorden with the locations of each adult ringed seal Pusa hispida male, female and subadult, collected on the fast-ice during May 2004. Area A covers $50 \mathrm{~km}^{2}$ of land-fast sea ice and Area B covers $38 \mathrm{~km}^{2}$ of sea ice 
macroscopically by making $2 \mathrm{~mm}$ thick longitudinal sections in each ovary with a scalpel. Females were defined as adult females $(\mathrm{N}=33)$ based on occurrence of corpora lutea or corpora albicantia or mature follicles (follicles $>6 \mathrm{~mm}$ ). Males were defined as adults, potentially participating actively in breeding, when they were $>7 \mathrm{yr}$ of age and spermatozoa were found in epididymis or spermatogenesis were detected in the seminiferous tubules (see Krafft et al. 2006b for details). Younger males were defined as juveniles. No pups of the year were collected.

A condition index (CI) was calculated as described in Krafft et al. (2006a). Briefly, CI = BlM/M ${ }^{0.75}$, where BlM is blubber mass and $M$ is body mass and $M^{0.75}$ is the metabolic body mass of the individual, according to Kleiber (1975). BlM was calculated based on a formula developed by Ryg et al. (1990a): $\mathrm{B}=4.44+5693$ $(\mathrm{L} / \mathrm{M})^{0.5} \times \mathrm{D}$, where $\mathrm{B}$ is blubber content $(\%)$, $\mathrm{L}$ is standard length $(\mathrm{m}), \mathrm{M}$ is body mass $(\mathrm{kg})$, and $\mathrm{D}$ is dorsal blubber thickness (m). This formula estimates the blubber content of phocid seals with less than $3 \%$ error. The resulting B was multiplied by M/100 to get the blubber mass (BlM) of the animal.

Testosterone levels in the blood plasma of adult males were measured using a commercially available kit (Spectria Testosterone, RIA, Orion Diagnostica).

GPS positions were programmed into ArcGIS software (ESRI ArcView, v8.3) for analyses of the ringed seal distribution. In one analysis, the adult males in the fast-ice area were split into 2 groups according to the number of neighboring adult females. This was done based on GPS position for each individual and simply counting the 6 closest neighbors for each adult male.

Most statistical analyses were done with STATISTICA v6.1 (StatSoft). Normality was confirmed by Kolmogorov Smirnov with the Lilliefors option test. Differences between groups with normally distributed data were determined using ANOVA (type III). To determine which group(s) differed significantly from each other, a post hoc Tukey's Honest Significant Dif- ference test (HSD for Unequal N) was employed. Differences in the proportions of males, females and subadults in Areas A and B were tested using a $\chi^{2}$ test. The statistical software SAS/STAT v6 (SAS Institute) was used for the regression analyses. Values are presented as means $\pm \mathrm{SE}$.

\section{RESULTS}

The ringed seals in this study $(\mathrm{N}=94)$ consisted of 19 adult males (age range: $8-30 \mathrm{yr}$ ), 33 adult females (age range: $6-27 \mathrm{yr}$ ) and 42 subadults (age range: $1-7 \mathrm{yr}$ ) (Table 1). When measuring the distance from the collection point of each seal in a straight east to west line to the shore (bottom of the fjord), a significant difference was found between these 3 groups of seals (ANOVA type III, $F=19.09$, p < 0.01) (Fig. 1). The positions of adult males in relation to the shore $(3.3 \pm$ $0.5 \mathrm{~km})$ differed from adult females $(1.9 \pm 0.2 \mathrm{~km}$, post hoc Tukey, $\mathrm{p}=0.02)$ and subadults $(4.4 \pm 0.3 \mathrm{~km})$ (post hoc Tukey, $\mathrm{p}=0.045$ ). Adult females also differed with respect to their distance to the shore compared to subadults (post hoc Tukey, $\mathrm{p}<0.01$ ).

If we consider the distribution of the various age and sex groups in relation to the stability of the ice, more adult females $(82 \%)$, more adult males (58\%) and fewer subadults (19\%) were located in the inner stable ice area compared to the outer, more unstable ice area $\left(\chi^{2}=151.50, \mathrm{df}=93, \mathrm{p}<0.01\right)$. Area B was occupied by 11 adult males and 26 adult females, giving an adult sex ratio in the prime breeding habitat of $1: 2.4$.

No differences were found between adult males in Area A versus Area B with respect to age, standard length, body mass, CI or testosterone levels (Table 2). A Multiple Regression Model examining the effects of testosterone levels of adult males showed no significant effect of age, standard length, CI or their distance to shore $(p>0.05)$; however, testosterone was found to

Table 1. Pusa hispida. Data on age and sex groups of ringed seals collected on the fast-ice of Kongsfjorden in May 2004. SL: standard length, BM: body mass, CI: condition index, DFS: distance from shore

\begin{tabular}{|lcccccc|}
\hline Animal category & $\mathrm{N}$ & $\begin{array}{c}\text { Age } \pm \mathrm{SE} \\
\text { (range) } \\
\text { yr }\end{array}$ & $\begin{array}{c}\mathrm{SL} \pm \mathrm{SE} \\
\text { (range) } \\
\mathrm{cm}\end{array}$ & $\begin{array}{c}\mathrm{BM} \pm \mathrm{SE} \\
\text { (range) } \\
\mathrm{kg}\end{array}$ & $\begin{array}{c}\mathrm{CI} \pm \mathrm{SE} \\
\text { (range) }\end{array}$ & $\begin{array}{c}\mathrm{DFS} \pm \mathrm{SE} \\
\text { (range) } \\
\mathrm{km}\end{array}$ \\
\hline Adult males & 19 & $15.0 \pm 1.2$ & $128.4 \pm 1.8$ & $73.1 \pm 3.2$ & $1.08 \pm 0.04$ & $3.3 \pm 0.5$ \\
& & $(8-30)$ & $(112-140)$ & $(47-89)$ & $(0.82-1.41)$ & $(0.5-8.1)$ \\
Adult females & 33 & $12.9 \pm 1.0$ & $126.2 \pm 1.2$ & $70.3 \pm 1.8$ & $1.32 \pm 0.03$ & $1.9 \pm 0.2$ \\
& & $(6-27)$ & $(111-140)$ & $(52-90)$ & $(0.74-1.68)$ & $(0.2-4.9)$ \\
Subadults & 42 & $3.3 \pm 0.4$ & $113.0 \pm 1.8$ & $51.6 \pm 2.2$ & $1.15 \pm 0.02$ & $4.4 \pm 0.3$ \\
& & $(1-7)$ & $(80-135)$ & $(20-84)$ & $(0.82-1.48)$ & $(0.7-7.5)$ \\
\hline
\end{tabular}


Table 2. ANOVA (type III) between adult male ringed seals collected in the unstable (Area A) and stable (Area B) parts of the fast-ice in Kongsfjorden in May 2004, using age, SL: standard length, BM: body mass, CI: condition index and testosterone levels as dependent variables

\begin{tabular}{|c|c|c|c|c|c|}
\hline $\begin{array}{l}\text { Dependent } \\
\text { variables }\end{array}$ & $\begin{array}{c}\text { Area A } \\
N=8\end{array}$ & $\begin{array}{l}\text { Area B } \\
\mathrm{N}=11\end{array}$ & $F$ & $\begin{array}{c}\mathrm{df} \\
\text { (residual) }\end{array}$ & $\mathrm{p}$ \\
\hline $\begin{array}{l}\text { Age } \pm \mathrm{SE} \\
\text { (range) yr }\end{array}$ & $\begin{array}{c}15.9 \pm 2.6 \\
(8-30)\end{array}$ & $\begin{array}{c}14.3 \pm 1.1 \\
(9-21)\end{array}$ & 0.35 & $1(17)$ & 0.6 \\
\hline $\begin{array}{l}\mathrm{SL} \pm \mathrm{SE} \\
\text { (range) } \mathrm{cm}\end{array}$ & $\begin{array}{c}128.3 \pm 2.8 \\
(119-139)\end{array}$ & $\begin{array}{c}128.5 \pm 2.5 \\
(112-140)\end{array}$ & 0.01 & $1(17)$ & 0.9 \\
\hline $\begin{array}{l}\mathrm{BM} \pm \mathrm{SE} \\
\text { (range) } \mathrm{kg}\end{array}$ & $\begin{array}{c}71.1 \pm 4.7 \\
(54-89)\end{array}$ & $\begin{array}{c}74.5 \pm 4.5 \\
(47-89)\end{array}$ & 0.26 & $1(17)$ & 0.6 \\
\hline $\begin{array}{l}\mathrm{CI} \pm \mathrm{SE} \\
\text { (range) }\end{array}$ & $\begin{array}{l}1.01 \pm 0.06 \\
(0.82-1.33)\end{array}$ & $\begin{array}{l}1.12 \pm 0.15 \\
(0.95-1.41)\end{array}$ & 2.23 & $1(17)$ & 0.2 \\
\hline $\begin{array}{l}\text { Testosterone } \pm \mathrm{SE} \\
\text { (range) } \mathrm{nmol} \mathrm{l}^{-1}\end{array}$ & $\begin{array}{l}1.9 \pm 0.7 \\
(0.4-7.0)\end{array}$ & $\begin{array}{l}2.2 \pm 0.6 \\
(0.1-7.1)\end{array}$ & 0.10 & $1(17)$ & 0.8 \\
\hline
\end{tabular}

Table 3. ANOVA (type III) between adult male ringed seals with $0-3$ neighboring adult females (Group 1) and 5-6 neighboring adult females (Group 2) collected in the inner Area (B) of the fast-ice in Kongsfjorden during May 2004, using age, SL: standard length, BM: body mass, CI: condition index, DFS: distance from shore and testosterone levels as dependent variables

\begin{tabular}{|c|c|c|c|c|c|}
\hline $\begin{array}{l}\text { Dependent } \\
\text { variables }\end{array}$ & $\begin{array}{c}\text { Group } 1 \\
\mathrm{~N}=7\end{array}$ & $\begin{array}{c}\text { Group } 2 \\
\mathrm{~N}=4\end{array}$ & $F$ & $\begin{array}{c}\mathrm{df} \\
\text { (residual) }\end{array}$ & $\mathrm{p}$ \\
\hline $\begin{array}{l}\text { Age } \pm \mathrm{SE} \\
\text { (range) yr }\end{array}$ & $\begin{array}{c}12.3 \pm 0.9 \\
(9-15)\end{array}$ & $\begin{array}{c}18.0 \pm 1.2 \\
(15-21)\end{array}$ & 14.00 & 1 (9) & $<0.01$ \\
\hline $\begin{array}{l}\mathrm{SL} \pm \mathrm{SE} \\
\text { (range) } \mathrm{cm}\end{array}$ & $\begin{array}{c}128.6 \pm 3.2 \\
(112-135)\end{array}$ & $\begin{array}{c}128.5 \pm 4.7 \\
(117-140)\end{array}$ & 0.00 & $1(9)$ & 1.0 \\
\hline $\begin{array}{l}\mathrm{BM} \pm \mathrm{SE} \\
\text { (range) kg }\end{array}$ & $\begin{array}{c}72.6 \pm 5.3 \\
(47-87)\end{array}$ & $\begin{array}{l}78.0 \pm 9.0 \\
(51-89)\end{array}$ & 0.31 & 1 (9) & 0.6 \\
\hline $\begin{array}{l}\mathrm{CI} \pm \mathrm{SE} \\
\text { (range) }\end{array}$ & $\begin{array}{l}1.16 \pm 0.07 \\
(0.98-1.41)\end{array}$ & $\begin{array}{l}1.06 \pm 0.04 \\
(0.95-1.15)\end{array}$ & 1.23 & 1 (9) & 0.3 \\
\hline $\begin{array}{l}\mathrm{DFS} \pm \mathrm{SE} \\
\text { (range) km }\end{array}$ & $\begin{array}{l}1.7 \pm 0.5 \\
(0.7-4.0)\end{array}$ & $\begin{array}{c}1.6 \pm 0.5) \\
(0.4-2.8\end{array}$ & 0.04 & $1(9)$ & 0.8 \\
\hline $\begin{array}{l}\text { Testosterone } \pm \mathrm{SE} \\
\text { (range) nmol } \mathrm{l}^{-1}\end{array}$ & $\begin{array}{l}1.8 \pm 0.5 \\
(0.5-4.7)\end{array}$ & $\begin{array}{c}2.87 \pm 1.49 \\
(0.1-7.07)\end{array}$ & 0.64 & $1(9)$ & 0.4 \\
\hline
\end{tabular}

interact significantly in a positive manner with body mass $(F=18.89, \mathrm{p}=0.03)$.

The division of adult males in the stable, fast-ice area into 2 groups according to numbers of neighboring adult females resulted in 7 males in Group 1 ( 0 -3 adult neighboring females) and 4 males in Group 2 (5-6 neighboring adult females). There were no significant differences related to standard length, body mass, CI, distance to shore or testosterone levels between adult males from these 2 groups (ANOVA type III, p > 0.05). However, the males with more female neighbors were significantly older (18 $\pm 1 \mathrm{yr}$ ) than the males with few female neighbors (12 \pm 1 yr) (ANOVA type III, $F=14.00, \mathrm{p}<0.01$ ) (Table 3).

\section{DISCUSSION}

This study has shown that breeding ringed seal females occupy the innermost, stable ice areas, while subadults are found on the outer areas of fast-ice where the ice conditions are more unstable. Adult males are scattered in between these 2 groups, with some intermingled with breeding females, while others are found further out towards the ice edge in areas dominated by subadults. This pattern strongly suggests territorial behavior with competitive exclusion of subadults and those adult males that cannot compete for territories in the prime breeding areas. These observations support earlier suggestions that have been made regarding the social structure of ringed seals, based on Inuit traditional knowledge, small-scale tracking studies and opportunistic observations of natural markings etc. (see below).

The 94 ringed seals in this study were collected by shooting from distances between 100 and $200 \mathrm{~m}$. At this relatively long distance, there were no indications that some age or sex groups were harder to approach than others. Additionally, because the sampling was performed over a short time period, and a standard, expected sex ratio of close to 1:1 (45:49) was achieved, we are quite confident that the spatial distribution pattern emerging from the sample is representative of the spatial distribution for all ringed seals that were present during the breeding season in May 2004. The temporal distribution of hunting was sex-skewed for adults, with the focus of the hunt being initially on males, with a switch to females in the latter part of sampling. However, total hunting effort was quite balanced between the sexes over the sampling interval.

Size differences in seals occupying different areas of pack-ice (adults vs. subadults) is a well known phenomenon among Inuit people (Furgal et al. 2002). The findings of this study confirm the general knowledge that younger, smaller animals occupy the outer, less stable land-fast ice areas, while older, larger animals occupy the inner, more stable areas of ice. The sex ratio found for adult ringed seals in the prime breeding area of Kongsfjorden of 2.4 females per male supports the suggestion of a slightly polygynous mating system, 
which has been suggested in earlier studies (Smith \& Hammill 1981, Stirling 1975, 1977, 1983, Kelly \& Quakenbush 1990). It is also similar to the ratio of 1:2.09 reported by Smith (1987). Unlike for terrestrial breeding seals, where large size of males seems to be an important factor for reproductive success, other factors seem more important for aquatically breeding seals, especially in cases where the breeding females are as widely distributed as in the case with ringed seals (Stirling 1975, 1983). The present study found that the larger ringed seal males had the highest levels of testosterone, but that these individuals were not the ones that had most adult female neighbors. The adult males with the most adult female neighbors were significantly older than adult males with fewer female neighbors, suggesting that experience is perhaps more important than size (and high testosterone levels) in determining reproductive success for male ringed seals. It is, however, worth noting that the 2 oldest males in this study (22 and $30 \mathrm{yr}$ old, respectively) were found in Area A (Fig. 1), outside the prime breeding ground, suggesting that there may be an optimal age interval for reproductive success among males.

Female spacing in ringed seals is set in part by the physical nature of the habitat. Lairs must be built where there is sufficient snow, and in Svalbard this occurs primarily where glacier ice pieces are frozen into the landfast annually formed fjord ice (Lydersen \& Gjertz 1986, Smith \& Lydersen 1991). Ringed seals are aggressive with one another and appear to defend lair structures (Smith \& Hammill 1981). But their dispersed distribution is also likely to be a response to predation pressure from polar bears and arctic foxes (Stirling 1977). The spacing of adult females and males in the innermost part of the fjord is similar to what would have been expected, based on the nature of the lairs, as described 20 yr ago in this fjord (Lydersen \& Gjertz 1986).

More subadult males than females were collected in this study, but this is due to the fact that females mature at a significantly younger age (Krafft et al. 2006b). Additionally, our definition of sexual maturity for the 2 sexes differed somewhat, resulting in some physically mature males being classified as subadults ( $<7 \mathrm{yr}$ of age). However, we think our classification probably reflects a reasonable approximation of social maturity, given the fact that most male pinnipeds are several years beyond sexual maturity when they enter the breeding population (e.g. Fay 1982, Kovacs 1990).

A few adult females were found in the outer, less stable areas in this study (Area A, Fig. 1); these individuals might be mothers whose pups were killed early in the season, and hence mated early and left the fast-ice areas. The outer parts of Kongsfjorden are more productive than the inner area (Hop et al. 2002) and there is no specific reason for females without pups to stay in the inner area. Many females lose their pups to arctic fox predation early in the nursing period, and a variable number of polar bear visits are responsible for additional pup mortality throughout the remaining part of the nursing period (Lydersen \& Gjertz 1986).

The inner parts of Kongsfjorden (Area B, Fig. 1) have predictably stable ice-conditions each spring, mainly due to the many small islands that protect this area from wind and wave action. In addition, this area usually has a significant number of icebergs calved into the fjord from several active glaciers, which get fixed in a somewhat annually variable pattern in the inner fjord when the ice forms in early winter. Drifting snow accumulates around these icebergs and these are the prime areas for ringed seal lairs in Kongsfjorden, similar to the other fjords in Svalbard (Smith \& Lydersen 1991). Sufficient snow accumulation on the sea ice is likely a limiting resource in Svalbard, as this arctic desert gets quite limited amounts of annual precipitation. Thus, the inner part of Kongsfjorden is a predictably good breeding area for ringed seals with respect to ice-stability and possibilities for lair construction. Food availability may be another factor determining the quality of ringed seal habitat. Even if ringed seal females rely on blubber stores to cover some of the costs of lactation (Ryg et al. 1990b), a large proportion of this energetically demanding process must depend on relatively heavy foraging (Lydersen 1995). The main prey items for ringed seals in this area are polar cod Boreogadus saida and crustaceans (Gjertz \& Lydersen 1986, Weslawski et al. 1994, Labansen 2005). The Kongsfjorden area is generally considered to be very productive, supporting ringed seals and many other species of marine mammals as well as numerous species of seabirds that forage at the edge of the fast-ice and beyond (Hop et al. 2002). Previous investigations have shown that there is a high density of birth lairs in this area (Lydersen \& Gjertz 1986). Since this area is usually very predictable with respect to ice stability, opportunities to construct lairs, and food availability, it could be expected that adult animals return annually to Kongsfjorden to breed. There are a few mark-recapture events supporting this assumption; adult animals have been marked and then recaptured in the next year or after several years some few $100 \mathrm{~m}$ from where they were marked (C. Lydersen $\&$ K. Kovacs unpubl. data). This means that some adult males may mate with the same females in successive years. Small amounts of data suggesting both intraannual and inter-annual site fidelity have also been reported previously for breeding ringed seals in other studies (McLaren 1958, Smith \& Hammill 1981, Kelly \& Quakenbush 1990). But there is also information from other areas strongly suggesting that there is considerable mobility among ringed seals in some areas. 
Harvests of ringed seals by humans or polar bears well above sustainable levels are sustained in some locales for long periods of time via recolonization from the broader range of the population (Smith 1973, Hammill \& Smith 1991). Currently, little is known about the structure of ringed seal populations, the degree of natural mobility between breeding areas, or the levels of exchange that take place across subpopulation or population boundaries.

Studying social behaviour of ringed seals is challenging, but mounting evidence from a diverse array of sources, including this study, supports a mating system based on territorial defense by males, that results in low-level polygyny. Integration of a variety of new tracking and observational technology may provide more in-depth analyses of ringed seal social behaviour via longitudinal studies of individual animals in the water as well as on the ice surface in the not-to-distant future (e.g. Simpkins et al. 2001, Davis et al. 2003, Mitani et al. 2004).

Acknowledgements. Financial support for this project was provided by the Norwegian Research Council and the Norwegian Polar Institute. In addition, student grants were awarded to B.A.K. from The Fishery Research Grant, University of Tromsø, The Norwegian Polar Institute's Arctic Stipend and The Roald Amundsen Centre for Arctic Research. We thank K. Ø. Gjelland, N. Krafft Skolleborg, I. Krafft Vestel, A. Krafft, H. Wolkers, A. Labansen and C. Johansen for help during the field collection. Thanks also to J. Aars (NPI) for help with the regression analysis. Comments from 3 anonymous reviewers helped us to improve this manuscript.

\section{LITERATURE CITED}

Boness DJ (1991) Determinants of mating systems in the Otariidae (Pinnipedia). In: Renouf D (ed) Behaviour of pinnipeds. Chapman \& Hall, London, p 1-44

Boness DJ, Bowen WD, Francis JM (1993) Implications of DNA fingerprinting for mating systems and reproductive strategies of pinnipeds. Symp Zool Soc Lond 66:61-93

Boness DJ, Clapham PJ, Mesnick SL (2002) Life history and reproductive strategies. In: Hoelzel AR (ed) Marine mammal biology, an evolutionary approach. Blackwell, Oxford, p 278-324

Bowen WD (1991) Behavioural ecology of pinniped neonates. In: Renouf D (ed) The behaviour of pinnipeds. Chapman \& Hall, London, p 66-127

Clutton-Brock TH (1989) Mammalian mating systems. Proc R Soc Lond B 236:339-372

Costa DP, Williams TM (1999) Marine mammal energetics. In: Reynolds III JE, Rommel SA (eds) Biology of marine mammals. Smithsonian Institution Press, Washington, DC, p 176-217

Davis RW, Fuiman LA, Williams TM, Horning M, Hagey W (2003) Classification of Weddell seal dives based on 3dimensional movements and video-recorded observations. Mar Ecol Prog Ser 264:109-122

Fay F (1982) Ecology and biology of the Pacific walrus, Odobenus rosmarus divergens Illiger. Fish \& Wildl Ser,
North American Fauna 74, Washington, DC

Fedoseev GA (1975) Ecotypes of ringed seal (Phoca hispida Schreber, 1777) and their reproductive capabilities. Rapp P-V Réun Cons Int Explor Mer 169:156-160

Fedoseev GA, Yablokov AV (1964) Morphological characteristics of the ringed seal (Pusa hispida, Pinnipedia, Mammalia) in the Okhotsk Sea. Zool Zhur 44:749-765 (English summary)

Finley KJ, Miller GW, Davis RA, Koski WR (1983) A distinctive large breeding population of ringed seals (Phoca hispida) inhabiting the Baffin Bay pack ice. Arctic 36: 162-173

Furgal CM, Innes S, Kovacs KM (1996) Characteristics of ringed seal, Phoca hispida, subnivean structures and breeding habitat and their effects on predation. Can J Zool 74: 858-874

Furgal CM, Innes S, Kovacs KM (2002) Inuit spring hunting techniques and local knowledge of the ringed seal in Arctic Bay (Ikpiarjuk), Nunavut. Polar Rec 21(2):1-16

Gentry RL (1998) Behavior and ecology of the northern fur seal. Princeton University Press, Princeton, NJ

Gjertz I, Lydersen C (1986) The ringed seal (Phoca hispida) spring diet in northwestern Spitsbergen, Svalbard. Polar Res 4:53-56

Hammill MO, Smith TG (1991) The role of predation in the ecology of the ringed seal in Barrow Strait, Northwest Territories, Canada. Mar Mamm Sci 7:123-135

Hammill MO, Lydersen C, Ryg M, Smith TG (1991) Lactation in the ringed seal (Phoca hispida). Can J Fish Aquat Sci 48: 2471-2476

Hop H, Pearson T, Hegseth EN, Kovacs KM and 24 others (2002) The marine ecosystem of Kongsfjorden, Svalbard. Polar Res 21:167-208

Kelly BP, Quakenbush LT (1990). Spatiotemporal use of lairs by ringed seals (Phoca hispida). Can J Zool 68:2503-2512

Kleiber M (1975) The fire of life. An introduction of animal energetics. RE Krieger, Huntington, NY

Kovacs KM (1990) Mating strategies in male hooded seals (Cystophora cristata). Can J Zool 68:2499-2502

Krafft BA, Lydersen C, Kovacs KM (2006a) Serum haptoglobin concentrations in ringed seals (Pusa hispida) from Svalbard, Norway. J Wildl Dis 42(2):442-446

Krafft BA, Kovacs KM, Frie AK, Haug T, Lydersen C (2006b) Growth and population parameters of ringed seals (Pusa hispida) from Svalbard, Norway, 2002-2004. ICES J Mar Sci 63(6):1136-1144

Krafft BA, Kovacs KM, Andersen A, Aars J, Lydersen C, Ergon T, Haug T (2006c) Abundance of ringed seals (Pusa hispida) in the fjords of Spitsbergen, Svalbard, during the peak molting period. Mar Mamm Sci 22:394-412

Labansen AL (2005) Spring diet of ringed seals (Pusa hispida) from north-western Spitsbergen, Norway. MSc thesis, University of Tromsø

Labansen AL, Lydersen C, Haug T, Kovacs KM (2007) Spring diet of ringed seals (Pusa hispida) from north-western Spitsbergen, Norway. ICES J Mar Sci (in press)

LeBoeuf BJ (1991) Pinniped mating systems on land, ice and in the water: emphasis on the Phocidae. In: Renouf D (ed) Behaviour of pinnipeds. Chapman \& Hall, London, p 45-65

Lydersen C (1995) Energetics of pregnancy, lactation and neonatal development in ringed seals (Phoca hispida). In: Blix AS, Walløe L, Ulltang Ø (eds) Whales, seals, fish and man. Elsevier Science, Amsterdam, p 319-327

Lydersen C, Gjertz I (1986) Studies of the ringed seal (Phoca hispida, Schreber 1775) in its breeding habitat in Kongsfjorden, Svalbard. Polar Res 4:57-63 
Lydersen C, Gjertz I (1987) Population parameters of ringed seals (Phoca hispida Schreber, 1775) in the Svalbard area. Can J Zool 65:1021-1027

Lydersen C, Hammill MO (1993a) Diving in ringed seal (Phoca hispida) pups during the nursing period. Can J Zool 71: 991-996

Lydersen C, Hammill MO (1993b) Activity, milk intake and energy consumption in free-living ringed seal (Phoca hispida) pups. J Comp Physiol B 163:433-438

Lydersen C, Kovacs KM (1999) Behaviour and energetics of ice-breeding, North Atlantic phocid seals during the lactation period. Mar Ecol Prog Ser 187:265-281

Lydersen C, Smith TG (1989) Avian predation on ringed seal Phoca hispida pups. Polar Biol 9:489-490

Lydersen C, Hammill MO, Ryg MS (1992) Water flux and mass gain during lactation in free living ringed seal (Phoca hispida) pups. J Zool Lond 228:361-369

McLaren IA (1958) The biology of the ringed seal (Phoca hispida Schreber) in the eastern Canadian Arctic. Fish Res Board Can Bull 188:1-98

Mitani Y, Watanabe Y, Sato K, Cameron MF, Naito Y (2004) 3D diving behavior of Weddell seals with respect to prey accessibility and abundance. Mar Ecol Prog Ser 281: 275-281

Ryg M, Lydersen C, Markussen NH, Smith TG, Øritsland NA (1990a) Estimating the blubber content of phocid seals. Can J Fish Aquat Sci 47:1223-1227

Ryg M, Smith TG, Øritsland NA (1990b) Seasonal changes in body mass and body composition of ringed seals (Phoca hispida) on Svalbard. Can J Zool 68:470-475

Ryg M, Solberg Y, Lydersen C, Smith TG (1992) The scent of rutting male ringed seals (Phoca hispida). J Zool Lond 226: 681-689

Simpkins M, Kelly BP, Wartzok D (2001) Three-dimensional diving behaviors of ringed seals (Phoca hispida). Mar Mamm Sci 17(4):909-925

Smith TG (1973) Population dynamics of the ringed seal in the Canadian eastern Arctic. Bull Fish Res Board Can, No. 181

Smith TG (1976) Predation of ringed seal pups (Phoca hispida) by the arctic fox (Alopex lagopus). Can J Zool 54:1610-1616

Smith TG (1980) Polar bear predation of ringed and bearded

Editorial responsibility: Otto Kinne (Editor-in-Chief), Oldendorf/Luhe, Germany seals in the land-fast sea ice habitat. Can J Zool 58: 2201-2209

Smith TG (1987) The ringed seal, Phoca hispida, of the Canadian western Arctic. Can Bull Fish Aquat Sci 216:1-81

Smith TG, Hammill MO (1981) Ecology of the ringed seal, Phoca hispida, in its fastice breeding habitat. Can J Zool 59: 966-981

Smith TG, Lydersen C (1991) Availability of suitable land-fast ice and predation as factors limiting ringed seal populations, Phoca hispida, in Svalbard. Polar Res 10:585-594

Smith TG, Stirling I (1975) The breeding habitat of the ringed seal (Phoca hispida). The birth lair and associated structures. Can J Zool 53:1297-1305

Smith TG, Stirling I (1978) Variation in the density of ringed seal (Phoca hispida) birth lairs in the Amundsen Gulf, Northwest Territories. Can J Zool 56:1066-1071

Smith TG, Hammill MO, Taugbøl G (1991) A review of the developmental, behavioural and physiological adaptations of the ringed seal, Phoca hispida, to the life in the arctic winter. Arctic 44:124-131

Stirling I (1975) Factors affecting the evolution of social behaviour in the pinnipedia. Rapp P-V Réun Cons Int Explor Mer 169:205-212

Stirling I (1977) Adaptations of Weddell and ringed seals to exploit the polar fast ice habitat in the absence or presence of surface predators. In: Llano GA (ed) Adaptations within Antarctic ecosystems. Gulf, Houston, TX, p 741-748

Stirling I (1983) The evolution of mating systems in pinnipeds. Spec Publ Am Soc Mammal 7:489-527

Tinker TM, Kovacs KM, Hammill MO (1995) The reproductive behaviour and energetics of male grey seals (Halichoerus grypus) breeding on a land-fast ice substrate. Behav Ecol Sociobiol 36:159-170

Tryland M, Krafft BA, Lydersen C, Kovacs KM, Thoresen SI (2006) Serum chemistry of free-ranging ringed seals (Pusa hispida) in Svalbard. Vet Clin Path 35(4):405-412

Weslawski JM, Ryg M, Smith TG, Øritsland NA (1994) Diet of ringed seals (Phoca hispida) in a fjord of West Svalbard. Arctic 47:109-114

Wiig Ø, Derocher AE, Belikov SE (1999) Ringed seals (Phoca hispida) breeding in the drifting pack ice of the Barents Sea. Mar Mamm Sci 15:595-598

Submitted: October 25, 2005; Accepted: June 7, 2006

Proofs received from author(s): March 29, 2007 